PUNISHMENT IN PARADISE 

PETER M. BEATTIE

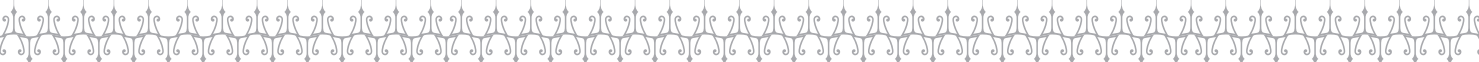

\title{
PUNISHMENT IN PARADISE
}

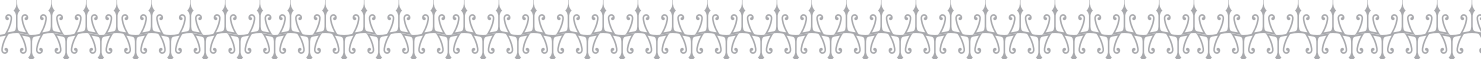

\author{
RACE, SLAVERY, \\ HUMAN RIGHTS, AND A \\ NINETEENTH-CENTURY \\ BRAZILIAN \\ PENAL COLONY
}


(C) 2015 Duke University Press

All rights reserved

Printed in the United States of America on acid-free paper $\infty$ Designed by Heather Hensley

Typeset in Minion Pro by Westchester Publishing Services

Library of Congress Cataloging-in-Publication Data

Beattie, Peter M., 1963-

Punishment in paradise : race, slavery, human rights, and a

nineteenth-century Brazilian penal colony / Peter M. Beattie.

pages $\mathrm{cm}$

Includes bibliographical references and index.

ISBN 978-0-8223-5816-9 (hardcover : alk. paper)

ISBN 978-0-8223-5830-5 (pbk. : alk. paper)

ISBN 978-0-8223-7589-o (e-book)

1. Prisons-Brazil-Fernando de Noronha-History—19th century. 2. Prisoners-Brazil-Fernando de Noronha.

3. Fernando de Noronha (Brazil)-History—19th century.

I. Title.

HV9594.F47B43 2015

$365^{\prime} \cdot 34-\mathrm{dc} 23 \quad 2014034850$

Duke University Press gratefully acknowledges the support of Michigan State University, Department of History, which provided funds toward the publication of this book.

Cover art: Fernando de Noronha Island, 2008. Photo by Bruno Barbey. @ Bruno Barbey / Magnum Photos. 
I dedicate this book to my wife, ERICA MELISSA WINDLER BEATTIE And to my son, AODHAN WINDLER BEATTIE The two souls most responsible for my regeneration. 

The Idée Fixe

So, long live history, voluble history, which is good at anything, and, getting back to the idée fixe, let me say that it's what produces strong men and mad men. A mobile idea, vague or changeable, is what produces a Claudius-according to the formula of Suetonius.

\section{A Project}

The need to regenerate him [Quincas Borba], get him back to working and having respect for his person was filling my heart. I [Brás Cubas] was starting to get a comfortable feeling, one of uplift, of admiration for myself.

JOAQUIM MARIA MACHADO DE ASSIS, THE POSTHUMOUS MEMOIRS OF BRÁS CUBAS 
